\title{
The Link between Analysis Dimension of Strategic Orientation and Firm Performance in Small and Medium Enterprises in the Hospitality Industry in Kenya: The Moderating Role of Top Manager's Ownership Status
}

\author{
Martha C. Cheluget ${ }^{1 *}$, Caroline J. S. Koech ${ }^{2}$ \\ 1. Division of Planning and Development, Moi University, Eldoret, Kenya. \\ 2. School of Business \&Economics, Jaramogi Oginga Odinga University of Science and Technology, Bondo, \\ Kenya.
}

*Corresponding author: Martha C. Cheluget

\begin{abstract}
Performance of Small and Medium Enterprises (SMEs) is important for the economic success of nations, and strategic orientation is documented as one of the critical success factors for business firms. However, empirical studies have yielded varied results on the influence of the various dimensions of strategic orientation under different conditions. Furthermore most studies have focused on large firms and more so in developed countries. The primary objective of this study was to examine the effect of analysis dimension of strategic orientation on the performance of SMEs in a developing economy. The study employed explanatory research design. Data was collected from a sample of 390 hotel and food service SMEs and was analyzed using descriptive and inferential statistics. Pearson Correlation was used to test for linear relationships between the variables while the research hypotheses were tested using multiple regression models. The findings indicated that Analysis dimension has statistically significant $(B=0.929$, $\rho<0.05)$ and positive effect on firm performance. However, the study found that although top managers' ownership status had statistically significant direct effect $(B=0.264, \rho<0.05)$ on performance, its moderating effect $(B=0.080, \rho>0.05)$ on the relationship between analysis dimension and firm performance was not significant. The study thus concluded that Analysis dimension significantly and positively affects firm performance in SMEs regardless of the ownership status of the top managers and recommends for managers and policy makers to focus on analysis strategies in order to enhance firm performance in SMEs.
\end{abstract}

Keywords: Analysis dimension, Firm performance, Strategic Orientation, and Top Managers.

\section{Introduction}

Small and Medium Enterprises are found across nations in different industries and they form a sector that is increasingly being recognized as a major vehicle for economic development in nations, both developed and developing. It is for this reason that the performance of SMEs is considered important not just to the stakeholders who expect maximum value on their investment but to the development of nations. The SME sector is valued as a contributor to development of any nation, as it is a vital source of employment, revenue generation, innovation and technological advancement [1-2] development of new products, processes and ideas and supply chain to multinationals.
According to World Bank SME Finance Report [3], formal SMEs contribute up to $45 \%$ of total employment and up to $33 \%$ of national income (GDP) in emerging economies and in Sub-Saharan Africa, SMEs make up $95 \%$ of all firms [4]. Kenya, like many developing countries attaches a lot of importance on its SME sector and has given it prominence as one of the drivers of its current national development plan [5] where it is identified as a key engine for economic growth, poverty eradication and employment creation and the bedrock for industrializing the country. The country's SME sector consists of firms varying in size and industry type, ranging from very small start-up firms 
(Micro) to those established and listed on the stock market.

The Kenya Economic Survey estimated the number of micro, small and medium enterprises at 7.5 million, providing employment and income generation opportunities to low income sectors of the economy. According to the report, the sector contributed up to approximately $80 \%$ of total employment and $33.8 \%$ of the GDP in 2015.

To support the sector, the Kenya government has enacted a law to guide the development and sustainability of micro-finance institutions and established an authority to oversee the implementation of the Micro and Small Enterprises. It has also created the Financial Sector Deepening (FSD) programme in collaboration with partners (such as UK's Department for International Development (DFID), the Swedish International Development Agency (SIDA), and the Bill and Melinda Gates) whose goal is to expand access to financial services among low income households and smaller enterprises.

\section{Statement of the Problem}

The performance of small and medium enterprises has been given importance in building economies particularly in developing nations, such as Kenya, where they play a key role as a source of employment and contributes to the GDP. According to the National Economic Survey report by the Central Bank of SMEs make up 98 percent of all business in Kenya, create 30 percent of jobs annually and contribute 3 percent of the GDP.

Notwithstanding the apparent significance associated with SME firms and the policy initiatives and support programs put in place, the SME firms in Kenya have not reached their full potential, with very high mortality rates being reported. For instance, a survey by the Kenya National Bureau of Statistics [6] indicates that approximately 400,000 micro, small and medium enterprises do not survive beyond two years and few reach five years. This clearly implies that sustainability of this critical sector is still a concern. The sustainability problem in Kenya's SMEs has been attributed to several factors spanning, inadequate capital, limited market access, poor infrastructure, inadequate knowledge and skills and rapid changes in technology emanating from the highly competitive markets as well as management related issues The gap identified between the prominence given to SME sector and its performance and growth has generated widespread interest among researchers and scholars, predominantly in the disciplines of entrepreneurship and strategic management. Some studies indicate that small and medium firms are not able to operate at their optimum due to multiple challenges including, financing investment and working capital, unavailability of appropriate and timely information technology, lack of human resource skills, weak management systems and entrepreneurial capabilities and poor product quality [7].

Others attribute the poor performance to the fact SMEs are now faced with competition not only from their peers but also from the large firms that are increasingly venturing in niche markets that hitherto were their preserve [8]. The research community sharing the view that growing SMEs are of special importance in the economy has undertaken several studies [9-10] and point to the importance of strategic management for SME performance and growth.

Such studies have investigated various factors proposed as determinants or antecedents of performance and growth in SMEs, mainly on aspects related to competitive strategy, management strategies, strategic orientation, characteristics of the entrepreneur, environmental/industryspecific factors, and the characteristics of the firm among others. However, the studies have yielded mixed findings in terms of factors being proposed as determinants of SME performance and growth, thus pointing to the need for more studies in this area. Extant literature, for instance points to the insufficient research evidence on the significance, value and process of strategy and strategic management for SMEs [11-12].

Although there is empirical evidence to support the assertion that strategic orientation leads to superior firm performance [13] concurrence is yet to be reached in terms of its dimensions. A number of studies have recommended strategic orientations as ways of building firm competitive advantage in order to enhance firm performance [14-15-16-17-18]. 
Nevertheless, research findings pertaining to the impact of specific strategic orientations in SME firms have indicated varied findings under different conditions such as industry type, geographical location and nations' level of economic development among others and hence the need for more research in this area. Furthermore in the studies linking strategic orientation and firm performance in SMEs, some findings have revealed that the link differs in various backgrounds due to contingent factors that play moderating and or mediating influence and as such have called for studies focused on investigating intervening factors to model the strategic orientation- performance relationship effectively [19].

Some of the different backgrounds and contexts of SMEs relate to industry type and firm characteristics. Related studies have established that managers play an important role in determining corporate outcomes [2021-22] while studies on management structures of SMEs point to the influence of managers' ownership status on firm performance with many indicating that owner-managed firms outperform the nonowner managed [23-24].

This study therefore investigated the link between analysis dimension of strategic orientation and firm performance in SMEs in the context of a developing economy in a single industry looking at the ownership status of top managers as a moderating variable. It focused on analysis strategic orientation as a determinant of firm performance in SME firms looking at it from the comparative approach which seeks to evaluate strategy by way of multiple traits or dimensions common to all firms.

\section{Review of Related Literature}

\section{Firm Performance}

Firm performance is widely accepted as the main goal of any business enterprise and its importance has been indicated not only for the business firms but also for nations and society at large. The concept of firm performance has generated extensive research interest where it is mostly studied as a dependent variable and the ultimate measure of business success. It is a construct of diverse nature with various definitions and variables being used by both academia and industry practitioners.
However, it generally refers to business success. The theoretical background applied to conceptualize firm performance in this study is the stakeholder's theory [25]. This theory has been recognized by different authors [26-27] for the reason that it allows one to define firm performance with financial as well as nonfinancial aspects. From this perspective firm performance has been defined as stakeholder satisfaction [28].

In order to meet stakeholders' expectations, improving firm performance remains a central concern in firms of all types today and as postulated by the stakeholder theory, the firms' stakeholders expect managers to maximize their value. This calls for the understanding of the determinants of firm performance by managers of firms and policy makers. Strategic management has been linked to firm performance [29] and more so in the backdrop of the prevailing highly competitive market trends where firm's performance highly depends on sustainable competitive advantage. Strategy plays a crucial role in the firms' performance as it gives the direction that a firm has in mind and how to achieve its goals.

As argued by the Resource Based View (RBV) firms must effectively and efficiently translate their resources into unique capabilities [30] in order to realize sustainable competitive advantage in highly competitive environments. This study hence focused on the link between strategic orientation and firm performance from the resource based view perspective.

\section{Strategic Orientation}

Strategic orientation is a concept that has gained wide research attention in the field of strategic management with various definitions being applied but all of which view its final objective as being to achieve superior firm performance [31]. This is attributed to the focus of the strategic orientation concept which is about building competitive advantages and exploring new business opportunities through innovation, experimentation and risk-taking decisions; and sustaining competitive advantages by analysis, organizational planning and longterm vision. Strategic Orientation is widely understood as a way to combine or match strengths, weaknesses, opportunities and threats in order to arrive at a number of 
strategic options from which a choice can be made. It generates a number of realistic alternatives and provides a prioritization. In view of this, the strategic management field has produced a body of research focusing on the identification and the understanding of firm level strategic orientations within and across industries and featuring large and small firms. In literature, strategic orientation has been conceptualized through three theoretical perspectives: the narrative approach, which endeavors to describe in words the holistic nature of strategy which is unique to the event, situation, and organization; the classificatory approach which attempts to classify firms' strategy according to either ex ante conceptual arguments or ex post empirically derived groupings.

These classifications are known as typologies such as the one introduced by Miles and Snow [32] Generic strategies [33], market leadership [34], strategic windows [35] and High performance Gestalt [36]. The third approach is the comparative, which is associated with, and seeks to evaluate strategy by way of multiple traits or dimensions common to all firms. From the comparative approach, considered the nature of strategic orientation and conceptualized its component parts as having as many as six dimensions which are common to all firms namely, aggressiveness, analysis, defensiveness, futurity, proactiveness, and riskiness. These dimensions form the guiding principles of managers in developing appropriate strategies [37]. This study focused on the analysis dimension of strategic orientation. To focus on two issues

\section{Analysis Dimension of Strategic Orientation}

Analysis dimension refers to the ability to investigate deeply into the foundational causes of problems and develop the best alternative solution as a way of problemsolving. It relates to the maintenance of internal consistency in the resource allocation strategies towards the achievement of corporate objectives. The alignment of resource allocation and competitive intelligence are important issues of consideration [38]. Analysis refers to a firm's knowledge-building capacity [39] and ability to enhance organizational learning [40]. This orientation refers to the problemsolving approach of firms from their understanding of external and internal environment [41]. It reflects a firm's tendency to go to the deeper root of problems to generate the best possible alternatives which becomes an important characteristic of the organizational decision making. The whole aspect of this orientation bears close conformity to the idea of rational comprehensive processes [42], where in the observed phenomenon is that of analytical activities and systems relating positively with firm performance [43]. Based on these arguments, it is expected to be significantly related to SME growth.

\section{Strategic Orientation and Firm Performance}

Many researchers have related business strategies with performance, distinguishing between strategies associated with high and low performance. Researchers typically use strategic orientations to examine the link between firm strategy and performance [4445].The underlying assumption here is that substantive strategic beliefs underpin the strategic actions taken by the firm.

Strategic orientation has been viewed as an attribute that influences the ability of a firm to focus its strategic direction and build or sustain the proper strategic fit for superior firm performance. Scholars assert that firms of all types are increasingly faced with similar challenges brought about by the competitive landscape characterized by trends towards globalization, emerging new markets, deregulation and acceleration of technological change. Those of this view argue that it is how firms position themselves to fight for their survival that makes the difference in their performance [46].

The dynamic nature of the business environment therefore necessitates organizations, both SMEs and corporate, to be more strategic in their everyday approach to business and analysis dimension allows for the implementation of such an approach. The analysis dimension generally represents firm's approach to problem solving secured by understanding internal and external environmental contexts. It also includes the internal systems and procedures that facilitate the foundation and execution of competitive strategy to achieve firm objectives. 
The positive effect of analysis dimension on firm performance is attributed to its trait of analytical activities focusing on internal systems and procedures that facilitate the foundations and execution of competitive strategy. As posited by, analytical activities are critical for, and are likely to positively impact, business performance, regardless of the external environment.

\section{Top Managers' Ownership Status and Firm Performance}

Strategy implies choice and the notion of strategic orientation recognizes that given the same environments, similar firms may employ different competitive methods or strategies to address the environment. This, points to the vital role of managers in firm performance since they are the ones that make decisions on what strategies to follow.

This is even more crucial in the small and medium firms where the business owner and or the managers are responsible for the strategic decisions and the formulation of a firm's strategy. The strategy is therefore often strongly influenced by the distinct characteristics, competencies and unique knowledge of the owner / manager in SMEs [47]. Further, studies have established the influence of managers' characteristics on strategy choice such as social status, tenure, age, and gender. Recent research however calls for more characteristics beyond the demographics to better understand the influence of managers on firm performance. For instance the literature that compares the performance of owner-managed firms to those run by professional managers [48]. Such studies have indicated the influence of managers' ownership status on firm performance in different contexts.

Based on the extant literature the study postulated that analysis dimension strategies are likely to positively affect firm performance in SMEs while ownership status of top managers moderates the link between the two variables and therefore developed two hypotheses. The relationships between the variables were conceptualized as depicted in the conceptual framework (Fig 1). $\mathrm{H}_{1}$ The analysis dimension of strategic orientation significantly and positively affects firm performance in SMEs. $\mathrm{H}_{02}$ Top managers' ownership status positively moderates the relationship between analysis dimension of strategic orientation and firm performance in SMEs.

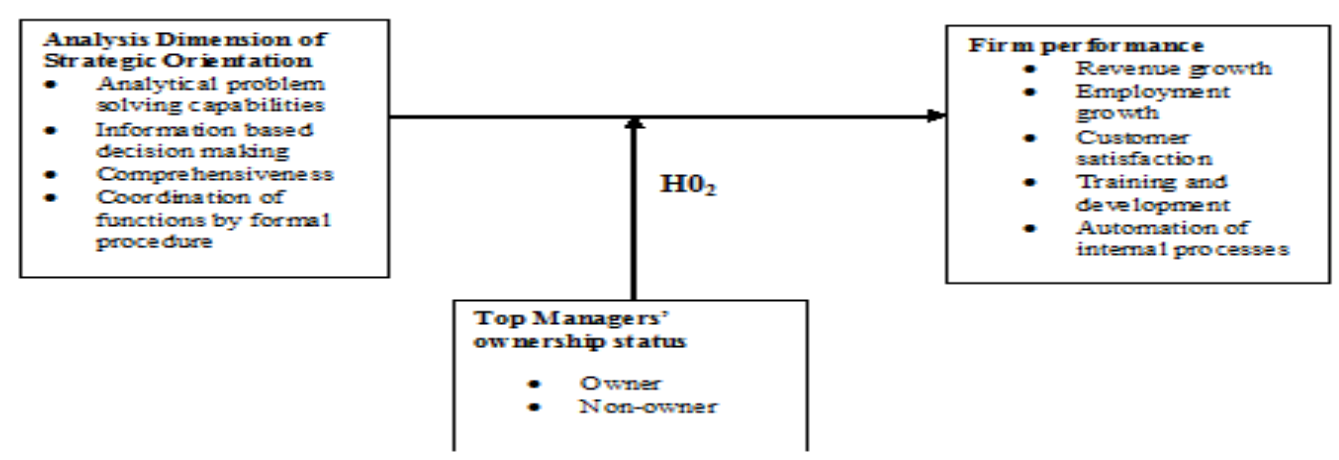

Figure 1Conceptual framework of the relationship between analysis strategic orientation and firm performance

\section{Methodology}

The study was carried in the northern part of Kenya's Rift Valley Region, which is made up of eight counties namely; Turkana, Baringo, Elgeyo Marakwet, Nandi, Uasin Gishu, West Pokot, Samburu and Trans-Nzoia. The region operates as an economic block known as North Rift Region Economic Bloc (NOREB). Samburu County was however omitted in the study due to insecurity in the area at the time of research. The region was identified for the study since it has a growing number of SME firms in the hospitality industry [49].
The study adopted an explanatory research design which was deemed appropriate in answering the study objective of establishing the causal relationship between study variables. A total of 902 hospitality SME firms licensed in the counties constituted the study population. A sample size of 385 was arrived at using the formula developed by Ma. Stratified random sampling technique was used to draw the sample as follows. The firms listed in the sample frame were categorized into two strata of firms offering 
distinctively different services/products, namely, hotel and accommodation (337 firms) and food service (575 firms). The sample size was then proportionately divided for the seven counties so as to ensure equal representation in the final sample of the study (Table 1). The rounding off decimals in calculations of proportionate sample sizes for each stratum per county increased the study sample size to 390. Random sampling technique was applied to draw out the sample. The respondents were top managers of the firms (Table 2).

Table 1: Proportionate Sample Size for Counties by Type of Firms

\begin{tabular}{|c|c|c|c|c|c|c|c|}
\hline \multirow[t]{2}{*}{ County } & \multicolumn{3}{|c|}{ Hotel and accommodation firms } & \multicolumn{4}{|c|}{ Food service firms } \\
\hline & $\begin{array}{c}\text { Number of } \\
\text { firms }\end{array}$ & $\begin{array}{c}\text { Percent } \\
\text { of total }\end{array}$ & $\begin{array}{l}\text { Proportional } \\
\text { no. of firms }\end{array}$ & $\begin{array}{l}\text { Number } \\
\text { of firms }\end{array}$ & $\begin{array}{l}\text { Percent } \\
\text { of total }\end{array}$ & $\begin{array}{c}\text { Proportional } \\
\text { no. of firms }\end{array}$ & Sample \\
\hline $\begin{array}{l}\text { Uasin- } \\
\text { Gishu }\end{array}$ & 186 & $20 \%$ & 77 & 323 & $35 \%$ & 135 & 212 \\
\hline Baringo & 38 & $4 \%$ & 16 & 61 & $6 \%$ & 23 & 39 \\
\hline Nandi & 22 & $2 \%$ & 8 & 43 & $4 \%$ & 16 & 24 \\
\hline West Pokot & 14 & $1 \%$ & 4 & 18 & $1 \%$ & 4 & 8 \\
\hline $\begin{array}{l}\text { Trans } \\
\text { Nzoia }\end{array}$ & 42 & $5 \%$ & 20 & 68 & $10 \%$ & 39 & 59 \\
\hline $\begin{array}{c}\text { Elgeiyo- } \\
\text { Marakwet }\end{array}$ & 14 & $5 \%$ & 20 & 39 & $4 \%$ & 16 & 36 \\
\hline Turkana & 11 & $1 \%$ & 4 & 23 & $2 \%$ & 8 & 12 \\
\hline Sub Total & 327 & $38 \%$ & 149 & 575 & $62 \%$ & 241 & 390 \\
\hline $\begin{array}{l}\text { Total } \\
\text { Firms }\end{array}$ & 327 & & & 575 & & & 902 \\
\hline
\end{tabular}

Data was collected using Likert type scale on the following measurements of the primal study variables. Analysis dimension of strategic orientation (predictor variable) was measured using 5 parameters adapted from Choy and Mula [50] originally adapted from venkatrakaman [51] namely: Analytical problem solving capabilities, Information based decision making, Comprehensiveness and Coordination of functions by formal procedure. Firm performance (independent variable) was measured using the following parameters: Revenue growth, Employment growth, Customer satisfaction, training and development and automation of internal processes. These were adapted from Bing LIU and Zhengping FU [52] and Gibson and Cassar [53].

The moderating, variable (managers' ownership status) was measured on two parameters: owner and non-owner, adapted from Lorenz et al [54]. A total of 390 questionnaires were administered and 378 were received back representing overall response rate of $96.9 \%$ out of which 375 were found valid for analysis. The reliability of the study measures was assessed using the Cronbach's Alpha.

The study instrument yielded alpha coefficients of 0.940 for firm performance and 0.692 for analysis dimension of strategic orientation. These were within the minimum coefficients of .60 deemed acceptable in social research [55-56].Tests of assumptions of regression were conducted to check the appropriateness of analyzing data using multiple regressions. The data set was checked for normality by visual inspection of the graphs and plots as well as examining the skew and kurtosis. Inspection of the histogram indicated a normal curve which shows normal distribution of data while the P-P plot revealed that data had a good fit with the normal line. The data skewness was in a range of -1.490 to -.113 which is within the acceptable range of -1.96 to 1.96 while the kurtosis range was between 3.357 and -.429 which was also well within the acceptable range of -10 to 10 as suggested by Doane and Seward [57].

The regression assumption of linearity was tested using Pearson moment correlation analysis. To counter multi-co linearity centering of variables was done. Examination of the correlation matrix (Table 3) shows that the correlations between the dependent variables and the independent variable are between the acceptable value range of +1 to 1 [58-59] and were all significant at $\mathrm{p}<0.05$ denoting linear relationship. Multicollinearity was checked against two criteria; Pearson's bivariate correlation among independent variables and Variance Inflation Factor (VIF). 
Inspection of the correlations among predictor variables revealed that all coefficients were less than 0.70 which is within acceptable limits [60]. All variables had VIFs well below the accepted maximum threshold of $+10-10$ as recommended by. The assumption of independence of errors was tested using Durbin-Watson accepted statistic range of $1.50-2.50$. The DurbinWatson statistic for the overall model containing all the variables was 1.817 signifying that the residuals are not correlated.

\section{Demographic Characteristics of the Respondents}

Demographic characteristics of the respondents were analyzed to understand the context of the study (Table 3.2). The study found that majority of the top managers were male making up $60.5 \%(n=224)$ while female were $39.5 \% \quad(n=146)$. This is in line with extant literature on SMEs in Kenya which illustrate that majority of those heading SME firms are male. In terms of age, the analysis indicated that majority of the top managers were in the bracket of 34 to 42 years $(n=127$, $34.3 \%)$ and those above 60 years of age $(n=9$, $2.4 \%$ ) were the least. In terms of education majority ( $\mathrm{n}=181,48.9 \%)$ had college diploma as their highest level of education, while those of secondary school level $(4.3 \%, \mathrm{n}=16)$ were the smallest group. This indicates that $95 \%(n=354)$ of all top managers had attained post-secondary school level.

Table 2 Demographic Profile of the Respondents

\begin{tabular}{|c|c|c|}
\hline Characteristics/variable & Frequency & Percentage \\
\hline Age in Years & & 5.9 \\
\hline $18-26$ & 22 & 21.9 \\
\hline $26-34$ & 8 & 34.3 \\
\hline $34-42$ & 127 & 25.4 \\
\hline $42-50$ & 94 & 2.4 \\
\hline $50-60$ & 37 & \\
\hline Over 60 & 9 & 60.5 \\
\hline Gender & & 39.5 \\
\hline Male & 224 & \\
\hline Female & 146 & 14.6 \\
\hline Education Level & & 32.2 \\
\hline University- post graduate & 54 & 48.9 \\
\hline University- undergraduate & 119 & 181 \\
\hline College & 16 & 0 \\
\hline
\end{tabular}

\section{Correlation Results}

The independent variable of the study, Analysis, was significantly and positively correlated $(\mathrm{r}=.590, \mathrm{p}<.001)$ with firm Performance. This supports the view that there is association between the predictor variable, and the dependent variable. The two control variables, firm age and firm size were also found to be significantly correlated with firm performance, (Firm Age, $\mathrm{r}=.589$, $\mathrm{p}<.001$ and firm Size, $\mathrm{r}=.496, \mathrm{p}<.001)$.

Table 3: Pearson Moment Correlations between Variables

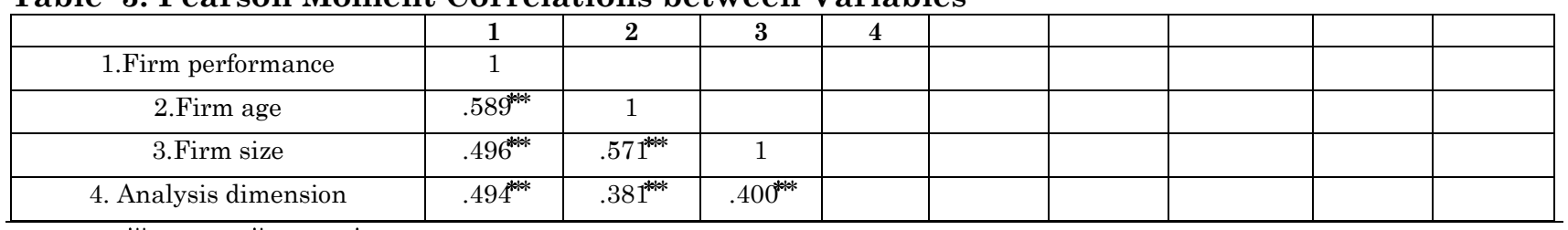

$\mathrm{P}<0.001^{* * *}, \mathrm{P}<0.05^{*}, \mathrm{P}<0.1^{*}$

\section{Testing of Hypotheses}

Regression analyses were conducted to test the hypotheses that guided the study. To test hypothesis $\mathrm{H}_{1}$, for direct relationship between analysis dimension and firm performance, the study first controlled for two variables, age and size in order to estimate the independent effect of the independent variable. This was necessary since past studies have established strong relationships between firm performance and the size and age of the firm [61]. 
Table 4: Multiple regressions results for direct effects

\begin{tabular}{|c|c|c|}
\hline Variables & Model 1 & Model 2 \\
\hline Constant & $1.980(.328)$ & $1.997(.329)$ \\
\hline Control Variables & & $.754(.111)^{* * *}$ \\
\hline Age of firm & $.949(.113)^{* * *}$ & $.578(.179)^{* *}$ \\
\hline Size of firm & $.936(.183)^{* * *}$ & $.929(.170)^{* * *}$ \\
\hline Independent Variable & & $.264(.075)^{*}$ \\
\hline Analysis dimension & & $80.075(.000)$ \\
\hline Top Management ownership status & & .468 \\
\hline F statistic & $119.843(.000)$ & .076 \\
\hline $\mathrm{R}^{2}$ & .395 & .462 \\
\hline $\mathrm{R}^{2}$ Change & .395 & 1.841 \\
\hline Adjusted R & .392 & 1.84 \\
\hline Durbin-Watson & 1.906 & \\
\hline
\end{tabular}

The results (Table 4) indicate in model 1 that the two control variables firm age $(B=.949$; $\mathrm{p}<.001)$ and firm size $(B=.936 ; \mathrm{p}<.001)$ had statistically significant effect on firm performance. The coefficient of determination $\mathrm{R}^{2}$ of .395 which is statistically significant at $\mathrm{P}<.001 \quad(.000)$ implies that the control variables explain $39.5 \%$ of variation in firm performance.

The overall model is statistically significant as indicated by $\mathrm{F}$ change statistic of 119.843 . The model fit is indicated by $\mathrm{R}^{2}$ with a value of .395 and adjusted $R^{2}$ at .392. After the Control variables, the predictor variable, analysis dimension of strategic orientation and the moderator variable were entered into the model. As shown in model 2 the entry of the predictors significantly increased the model's predictive ability in explaining change in firm performance by $7.6 \%$ as indicated by $\mathrm{R}^{2}$ change with a value of .076 . The change is statically significant at $\mathrm{p}<.001$ (Table 5). The overall model 2 is significant at $\mathrm{p}<.001 \mathrm{as}$ indicated by the $\mathrm{F}$ change statistic of 80.075 and explains $46.8 \%$ of variation in firm performance as indicated by the coefficient of determination $\mathrm{R}^{2}$ with a value of .468 .

The overall model fit is indicated by the coefficient of determination $\mathrm{R}^{2}$ with a value of .468 and adjusted $\mathrm{R}^{2}$ of .462. The study findings as seen in Table 6 established that there is a positive and statistically significant relationship $(B=.929 ; p<.05)$ between analysis dimension and firm performance and hence failed to reject the hypothesis Ho1. This implies that an increase in the levels of analysis dimension of strategic orientation will increase firm performance.

Table 5: Model 2 Summary

\begin{tabular}{|c|c|c|c|c|c|c|c|c|c|c|}
\hline \multirow[t]{2}{*}{ Model } & \multirow[t]{2}{*}{$\mathbf{R}$} & \multirow{2}{*}{$\begin{array}{c}\mathbf{R} \\
\text { Square }\end{array}$} & \multirow{2}{*}{$\begin{array}{c}\text { Adjusted R } \\
\text { Square }\end{array}$} & \multirow{2}{*}{$\begin{array}{l}\text { Std. Error of } \\
\text { the Estimate }\end{array}$} & \multicolumn{5}{|c|}{ Change Statistics } & \multirow{2}{*}{$\begin{array}{l}\text { Durbin } \\
\text { Watson }\end{array}$} \\
\hline & & & & & $\begin{array}{c}\text { R Square } \\
\text { Change }\end{array}$ & F Change & df1 & df2 & $\begin{array}{c}\text { Sig. F } \\
\text { Change }\end{array}$ & \\
\hline 1 & $.626^{\mathrm{a}}$ & .392 & 389 & 1.57814 & .392 & 118.166 & 2 & 366 & .000 & \\
\hline 2 & $.684^{\mathrm{b}}$ & .468 & .462 & 1.48061 & .076 & 25.903 & 2 & 364 & .000 & 1.841 \\
\hline
\end{tabular}

Table 6: Coefficients for Model 2

\begin{tabular}{|c|c|c|c|c|c|c|c|c|c|c|}
\hline \multirow{2}{*}{\multicolumn{2}{|c|}{ Model }} & \multicolumn{2}{|c|}{$\begin{array}{l}\text { Unstandardized } \\
\text { Coefficients }\end{array}$} & \multirow{2}{*}{$\begin{array}{c}\text { Standardized } \\
\text { Coefficients }\end{array}$} & \multirow[t]{2}{*}{$\mathbf{T}$} & \multirow[t]{2}{*}{ Sig. } & \multicolumn{2}{|c|}{$\begin{array}{c}95.0 \% \\
\text { Confidence } \\
\text { Interval for B }\end{array}$} & \multicolumn{2}{|c|}{$\begin{array}{c}\text { Collinearity } \\
\text { Statistics }\end{array}$} \\
\hline & & B & Std. Error & & & & $\begin{array}{l}\text { Lower } \\
\text { Bound }\end{array}$ & $\begin{array}{l}\text { Upper } \\
\text { Bound }\end{array}$ & Tolerance & VIF \\
\hline \multirow{3}{*}{1} & (Constant) & 1.997 & .329 & & 6.064 & .000 & 1.349 & 2.644 & & \\
\hline & Age of Firm & .948 & .114 & .432 & 8.352 & .000 & .725 & 1.171 & 622 & 1.608 \\
\hline & Size of Firm & .927 & .184 & .261 & 5.043 & .000 & .566 & 1.289 & 622 & 1.608 \\
\hline \multirow{5}{*}{2} & (Constant) & 3.303 & .359 & & 9.195 & .000 & 2.597 & 4.010 & & \\
\hline & Age of Firm & .754 & .111 & . 343 & 6.819 & .000 & .536 & .971 & .578 & 1.732 \\
\hline & Size of Firm & .578 & .179 & .163 & 3.226 & .001 & .226 & .931 & .576 & 1.736 \\
\hline & ANALYSIS_CENTRED & .929 & .170 & .238 & 5.474 & .000 & .595 & 1.262 & .775 & 1.290 \\
\hline & STATUS_CENTRED & .264 & .075 & .151 & 3.496 & .001 & .115 & .412 & .786 & 1.272 \\
\hline
\end{tabular}

Hierarchical moderated regression analysis was carried out following the steps outlined by to determine the moderating effect of top managers' ownership status on the relationship between analysis strategic orientation dimension and firm performance in SMEs as proposed in hypotheses $\mathrm{HO}_{2}$. The independent variables 
were first standardized to Z-scores so as to reduce the effects of multicollinearity and to simplify interpretations. In model 1 the two control variables; size and age of firm were entered. In model 2 all independent variables were entered and in the third model the interaction terms were added. Inspection of the $p$ values of the main effects indicate that those of the predictor variable, Analysis dimension (.000) and the control variables, age of the Firm (.000) and size of the firm (.000) were less than 0.05 and thus significant.

This implies that each of these variables independently influence firm performance. Ho2 stated that TM ownership status does moderates the relationship between analysis dimension of strategic orientation and firm performance. The results indicate that the main effect of analysis dimension on firm performance was positive and statistically significant $(B=.537 ; \mathrm{p}<.05)$ but the interaction effect of top managers' ownership status and Analysis dimension firm performance was not statistically significant $(B=.080 ; p>.05)$ and therefore rejected the hypothesis. This implies that the ownership status of Top Managers in the firm does not moderate the relationship between analysis dimension of strategic orientation and firm performance.

\section{Discussions and Conclusions}

The study findings indicate positive relationships between age and size of firms with business performance in SMEs implying that as a firm grows older and larger its performance is bound to improve. This finding concurs with previous research and theory. For instance as posited by and older firms not only enjoy economies of scale but also over time have built good business networks and good relationships with partners, customers and financial institutions and even good reputation in the market all of which are critical success factors.

The main objective of the study was to examine the relationship between analysis strategic orientation and firm performance in SMEs and to establish the moderating effect of top managers' ownership status on that relationship. The study findings established a positive and statistically significant $(B=.929 ; \quad \mathrm{p}<.05) \quad$ relationship between analysis dimension and firm performance. The results imply that analysis dimension positively influences firm performance. However the study did not establish any moderating effect of top managers' ownership status on the relationship between analysis dimension and firm performance. The finding is consistent with extant empirical literature which emphasizes virtues of formal strategic planning and analytical decision making.

According to firms adopting analysis strategy derive competitive advantage by drawing up competitive strategies based on systematic analytical activities such as collecting and interpreting information for managerial decisions. A study by found that firms that emphasized traits of analysis in their strategic orientation exhibit high levels of performance. Similar studies [63-64-65] also found that analysis had positive effect on business performance and generally concluded that strategic orientation dimensions are of importance to performance of corporate organizations and those firms can improve their business processes and achieve better effectiveness and efficiency through the engagement of strategic approaches.

Citroen [66] opines that information plays a crucial role in reducing uncertainty and judging alternative options. Effective strategic decisions are associated with step by step analysis of information thus organization executives taking the rational approach require to collect and use considerable information in a structured decision making. According to Karim [67] management information system is the factor to facilitate and attain efficient decision making in any organization while Adebayo [68] asserts that lack of relevant information required in decision making leads to poor organizational planning, inappropriate decision making, poor priority needs and defective programming of activities.

This finding is also in line with the resource based view of the firm which stresses that it is much more feasible to exploit external opportunities using existing resources in a new way rather than trying to acquire new skills for each different opportunity. The proponents of this view argue that organizations should look inside the 
company to find the sources of competitive advantage instead of looking at competitive environment for it [69]. The RBV approach, advocates that firms must translate efficiently and effectively their resources and capabilities into business process, otherwise they cannot expect to realize the competitive advantage potential of their resources. Hence analysis dimension strategies by focusing internally can aid the firm to translate their resources and capabilities to gain competitive advantage.

The results strongly suggest that analysis dimension positively influences firm performance. This is attributed to the analytical activities focusing on internal systems and procedures that facilitate the foundations and execution of competitive strategy. Such traits include internal consistency, knowledge building and organizational learning, use of information for decision making, and internal systems and procedures for execution of strategy. The study concludes that SME firms can leverage the analysis dimension of strategic orientation for competitive advantage.

\section{Recommendations}

The study holds some important insights for managers, policy makers and those who serve as consultants in supporting SMEs. Its findings provide empirical evidence pointing to the importance of analysis dimension of strategic orientation as a determinant of firm performance in SME firms in the hospitality industry. The study thus recommends for SME firms adoption of analysis strategic orientation dimension to improve firm performance. Specifically this

\section{References}

1. Piech K (2004) the knowledge -based economy in transition countries. IJEBR, Selected issue

2. Lad Zani, Vuuren

Entrepreneurship Training for Emerging SMEs in South Africa. Journal of Small Business Management 40(2).

3. World Bank report (2015: 2010) SME Finance.

4. Kauffmann C (2005) Financing SMEs in Africa, Policy Insights No.7. OECD. http:// www.oecd.org/dev/insights. involve analytical strategic activities including, seeking and using information for decision-making, operating information systems that provide support for decisionmaking, using formal procedures to coordinate decisions between different functional areas/departments, carrying out a thorough analysis when confronted with a major decision and approaching problemsolving by understanding of both internal and external environments.

The research findings are also deemed valuable in terms of policy making and practice at national and county government levels particularly for the North Rift Region where the study was conducted. The study findings can be useful in developing policy frameworks to guide in the attainment of sustainable performance and consequently growth of small and medium sized enterprises.

\section{Limitations of the Study and Recommendations for Further Research}

The scope of the study is limited to SMEs of one industry in one country, Kenya, thus it is recommended for similar studies to be extended to other industries or multi industry contexts in the same country and beyond. The study looked at analysis strategic orientation dimension, top managers' ownership status and firm performance at one point in time. Further research is recommended using longitudinal time span which is thought to provide more insights than the snap shot approach used in this study.

5. Kenya national development plan, Kenya Vision 2030 www.vision2030.go.ke/lib.

6. Kenya National Bureau of Statistics (2007) https://www.knbs.or.ke

7. Davidsson P, Wiklund J, (2000) Conceptual and empirical challenges in the study of firm growth, in Handbook of entrepreneurship, D. Sexton, H. Landström (eds.). Oxford: Blackwell.

8. Ntakobajira, N. (2013). Factors affecting the performance of Small and Micro Enterprises (SMEs) Traders at City Park 
Hawkers Market in Nairobi County, Kenya, Nairobi, Kenya.

9. Dobbs M, R Hamilton (2007) Small business growth: Recent evidence and new directions. Int. J. Entrepreneurial Behavior. Res., 13.

10. O'Regan N, Ghobadian A, Sims M (2006) Fast tracking innovation in manufacturing SMEs. Technovation

11. Mughan T, Lloyd-Reason L, Zimmerman C (2004) Management consulting and international business support for SMEs: need and obstacles. Education and Training Journal, 46(8/9):424-432.

12. Kraus S, Harms R, Schwarz E (2008) Strategic business planning and success in small firms. Int. J. Entrepreneurship and Innovation Management.

13. Poon JML, Ainuddin RA, Junit SH (2006) Effects of self-concept traits and entrepreneurial orientation of firm performance. International Small Business Journal, 24(1)

14. Shane S, Venkataraman S (2000) The promise of entrepreneurship as a field of research. Academy of Management Journal, 25(1): 217-226.

15. Ireland RD, Hitt MA, Sirmon DG (2003) A Model of Strategic Entrepreneurship: The Construct and its dimensions. Journal of Management 29(6).

16. Escriba-esteve A, Sanchez-peinado L, Sancez-peinado E (2008) International Small Business Journal. http//isb.sagepub.com/26/4/463.

17. Hitt MA, Ireland RD, Camp SM, Sexton DL (2001) Strategic Entrepreneurship: Entrepreneurial Strategies for wealth Creation. Strategic Management Journal 22 (Special Issue).

18. Morgan RE, Strong CA (2003).Business performance and dimensions of strategic orientation. Journal of Business Research, 56(3):163-176.

19. Lumpkin GT, Dess GG (1996) Clarifying the entrepreneurial orientation construct and linking it to performance. Academy of Management Review, 21(1).

20. Bertrand M, Schoar A (2003) Managing with style: The Effect of managers on firm policies. Quarterly Journal of Economics, 118.
21. Malmendier Ulrike, Tate Geoffrey (2009) Superstar ceos. The Quarterly Journal of Economics. 124. 1593-1638.

22. Barth E, Gulbrandsen T, Schøne P (2005) Family ownership and productivity: The role of owner-management. Journal of Corporate Finance11,1-2

23. Ronald C, Anderson David M, Reeb (2003) Founding-Family Ownership and Firm Performance: Evidence from the S\&P 500: The Journal of Finance 58, (3):1301-1328 : Published by: Wiley for the American Finance Association:http://www.jstor.org/stable/3 094581

24. Maury B (2006) Family ownership and firm performance: Empirical evidence from Western European corporations. Journal of Corporate Finance12,(2):321341.

25. Freeman RE (1984) Strategic management: A stakeholder approach, 1st ed.; Pitman Publishing Boston, MA, USA;24-25

26. Combs JT, Cook C, Shook (2005) the dimensionality of organizational performance and its implications for strategic management research. Eds.2 D.J Ketchen and D.D Bergh.

27. Choi J, Wang H (2009) Stakeholder relations and the persistence of corporate financial performance. Strategic Management Journal, 30: 895-907. http://dx.doi. org/10.1002/smj.759.

28. Bosse DA, Phillips RA, Harrison JS (2009) Stakeholders, reciprocity, and firm performance. Strategic Management Journal 30 (4)

29. Venkatraman N (1989) Strategic orientation of business enterprises: The Construct, dimensionality, and measurement. Management Science, $35(8)$.

30. Ray G, Barney JB, Muhanna WA (2004) Capabilities, business processes, and competitive advantage: Choosing the dependent variable in empirical tests of the resource-based view. Strategic Management Journal, 25(1):23-37.

31. Zhou K, Yim C, Tse D (2005) The Effects of Strategic Orientations on Technologyand Market-Based Breakthrough Innovations, J. Market. 69. 
32. Miles RE, Snow CC (1978) Organization strategy, structure, and process, New York(NY): http://search.global.epnet.com

33. Porter ME (1980) Competitive Strategy: Techniques for Analyzing Industries and Competitors, New York: Free Press.

34. Treacy M, Wiersema F (1995) The discipline of market leaders: Choose your customers, narrow your focus, and dominate your market. USA: Addison Wesley.

35. Abell D (1980) The Starting point in ptrategic planning. Prentice Hall.

36. Miller D (1992) The generic strategy trap. Journal of Business Strategy, 13- 1

37. Lau CM, Bruton GD (2011) Strategic orientations and strategies of high technology ventures in two transition economies. Journal of World Business 46 ,371-38

38. Abiodun AJ, Osibanjo O, Oyeniyi O (2011) Strategic orientations and technology policy: An empirical test of relationship in developing countries. Management Science Letters 1

39. Bourgeois III LJ (1980) Performance and consensus.

https://doi.org/10.1002/smj.4250010304

40. Cohen J (1969) Statistical power analysis for the behavior sciences. NY: Academic Press.

41. Miller D, Friesen PH (1982) Innovation in conservative and entrepreneurial firms: two models of strategic momentum. Strategic Management Journal, 3, 1-25.

42. Fredrickson JW, Mitchell RT. (1984). Strategic decision processes: comprehensiveness and performance in an industry with an unstable environment. Acad Manage J 1984;27.

43. Eisenhardt KM, Graebner ME (2007) Theory building from cases: opportunities and challenges. Academy of Management Journal 50.

44. Avci U, Madanoglu M, Okumus F (2011) Strategic orientation and performance of tourism firms: Evidence from a developing country. Tourism Management, 32,147-157.
45. Voss GB, Voss ZG (2002) Strategic orientation and firm performance in an artistic environment. Journal of Marketing, 64(1)

46. Meers KA, Robertson C (2007) Strategic Planning Practices in Profitable Small Firms in the United States. The Business Review, 7(1):302-307. Available from: EBSCO Host:

47. Postma TJBM, Zwart PS (2001) Strategic Research and Performance of SMEs. Journal of Small Business Strategy, 12, 52-64.)

48. Bertrand M, Schoar A (2006) The role of family in family firms" Journal of Economic Perspectives, 20.

49. Uasin Gishu Integrated Development Plan 2013-2018 (2013) http://www.kpda.or.ke/documents/CIDP/ Uasin\%20Gishu.pdf

50. Choy Samuel SM, Mula JM (2008) the impact of strategic orientation dimensions on business performance: a case study based on an international organization. Educational Research and Review 2(5):109-116,

51. Venkatraman N (1989) The concept of fit in strategy research: Toward verbal and statistical correspondence. Academy of Management Review, 14.

52. Bing Liz, Fu Z (2011) Relationship between strategic orientation and organizational performance in born global: A Critical Review, Int. J. Bus. Manage. 6 (3).

53. Global Entrepreneurship Monitor (2010) Malaysia, 2010 Gibson and Cassar (2005). Longitudinal analysis of relationships between planning and performance in small firms. Small Business Economics,25-3

54. Jensen MB, Johnson B, Lorenz E, Lundvall B-A (2007) Forms of knowledge and modes of innovation', Research Policy, 36- 5.

55. Hair JF, Black WC, Babin BJ, Anderson RE (2010) Multivariate data analysis, 7thedition, Prentice Hall, Upper Saddle River, New Jersey.

56. Bagozzi RP,Yi Y (1988) On the evaluation of structural equation models. Academy of Marketing Science Journal, 16. 
57. Doane DP, Seward LE(2011) Measuring skewness: A forgotten statistic. Journal of Statistics Education, 19(2).

58. Wong CC, Hiew PL (2005) Diffusion of mobile entertainment in Malaysia: Drivers and Barriers. Journal of Enformatika,5

59. Jahangir N, Begum,N (2008) The role of perceived usefulness, perceived ease of use, security and privacy, and customer attitude to engender customer adaptation in the context of electronic banking. African Journal of Business Management 2(1).

60. Hayes AF (2013) Introduction to mediation, moderation, and conditional process analysis: A regression-based approach. New York, NY: The Guilford Press-Bolin 2014

61. Takahashi SIY (2009) Entrepreneurs as decisive human resources and business: Performance for the Lao SMEs, Chinese Business Review, 8 (7):29-47.

62. LiPuma JA, Newbert Scott L (2011)The effect of institutional quality on firm export performance in emerging economies: a contingency model of firm age and size" Small Business Economics 40(8):17-84

63. Joachim AA, Stephen IA (2014) Strategic orientation and performance of agrobased firms in transition economy. African Journal of Business Management 8(13):495-501

64. Gupta R, Basu S (2008) Influence of dimensions of strategic orientation (so) on the growth of small firms \& resources as moderating variable: $\mathrm{A}$ study of Indian small \&medium enterprises (SMEs), Institute of Management Technology (IMT) Ghaziabad (India.)

65. Ersun AN, Karabulut AT (2013) Innovation management and marketing in global enterprises. International Journal of Business and Management, 8. (20).

http://dx.doi.org/10.5539/ijbm.v8n20p76

66. Citroen CL (2011) the role of information in strategic decision-making. International Journal of Information Management, 31(6):493-501.
67. Karim AK (2011) the significance of management information systems for enhancing strategic and tactical planning. Journal of Information Systems and Technology Management.82 São Paulo

68. Adebayo FA (2007) Management information system for managers. AdoEkiti: Green Line Publishers.

69. Rothaermel FT (2012) Strategic Management: Concepts and Cases. McGraw Hill/Irwin, 5

70. Ajayi IA, Fadekemi F(2007) The use of management information systems (MIS) in decision making in the South-West Nigerian Universities. Educational Research and Review, 2-5

71. Basu S, Gupta R (2013) Explorations of strategic orientation (SO) dimensions on small firm growth and the challenge of resources. European Journal of Business \& Management, 5(20): 2

72. Davidsson P (2004) Researching entrepreneurship. New York: Springer.

73. Davidsson P, Kirchhoff B, Hatemi-J A, Gustavsson H (2002) Empirical analysis of business growth factors using Swedish data. Journal of Small Business Management, 40(4).

74. Engelen et al (2012) Entrepreneurial orientation, firm performance and the moderating role of transformational leadership behaviors'. Journal of management, published online, 10 Aug DOI: 10.1177/014 Sage Publication

75. Garson GD (2012) Testing statistical assumptions. Statistical Publishing Associates, Asheboro, NC USA.

76. Kenya Economic Survey https://www.knbs.or.ke

(2009)

77. Mbugua SK, Njeru A, Tirimba OI (2014) Factors Affecting the Performance of Small and Micro Enterprises in Limuru Town Market of Kiambu County, Kenya. International Journal of Scientific and Research Publications, 4-12

78. Razali NM, Wah YB (2011) Power Comparisons of Shapiro-Wilk, Kolmogorov-Smirnov, Lilliefors and Anderson-Darling Tests. Journal of Statistical Modeling and Anlytics, 2. 
79. Smallbone D, Wyer P (2000) Growth and development in the small firm, in Carter, S. James-Evans, D. (Eds), Enterprise and Small Business, Prentice Hall, Harlow, 409-433.

80. Tsai WMH, MacMillan IC, Low MB (1991) Effects of strategy and environment on corporate venture success in industrial markets. J. Bus. Venturing 6 (1):9-28.

81. Venkatraman N, Ramanujam V (1986) Measurement of business performance in strategy research: A comparison of approaches. Academy of Management Review
82. Wall TD, Michie Patterson, Wood SJ, Sheeran West M (2004) On the Validity of subjective measures of company Performance. Personnel Psychology 57 (1).

83. Wiklund J, Shepherd D (2005) Entrepreneurial orientation and small business performance: a configurationally approach. Journal of Business Venturing. 20(1).

84. Wiklund J, Patzelt H, Shepherd D (2009) Building an integrative model of small business growth. Small Business Economics, 32-4. 